J. Clin. Chem. Clin. Biochem.

Vol. 14, 1976, pp. $173-176$

\title{
The Influence of D-Penicillamine on Enzymatic Activities: Glucose-6-phosphate Dehydrogenase. Correlation with Serum Levels Measured in Humans
}

\author{
By W. P. Raab and B. M. Gmeiner \\ Vienna University Medical School, Department of Medical Chemistry (Chairman: E. Kaiser, M. D.)
}

(Received May 16/October 17, 1975)

Summary: The influence of $D$-penicillamine on glucose-6-phosphate dehydrogenase of yeast (pure enzyme), human hemolysate, and human skin homogenate were determined. In high concentrations, $D$-penicillamine inhibits glucose6-phosphate dehydrogenase activity (concentrations above $6.7 \mathrm{mmol} / \mathrm{l}$, i. e. $1 \mathrm{~g} / \mathrm{l}$ ). $I n$ low concentrations, $D$-penicillamine exerts an indirect influence by removing some inhibiting metal ions, such as zinc. In human skin homogenates, an activating action of $D$-penicillamine on glucose-6-phosphate dehydrogenase activity occurs due to the chelation of metal ions.

\section{Der Einfluß von D-Penicillamin auf Enzymaktivitäten: Glucose-6-phosphat-Dehydrogenase}

Zusammenfassung: Der Einfluß von D-Penicillamin auf die Glucose-6-phosphat-Dehydrogenase-Aktivität von Hefe (Reinenzym), von Hämolysat menschlicher Erythrocyten und vom Homogenat menschlicher Haut wurde untersucht. In Konzentrationen ab $6,7 \mathrm{mmol} / \mathrm{l}(=1 \mathrm{~g} / \mathrm{l})$ entfaltet $D$-Penicillamin eine direkte Hemmwirkung auf die Glucose-6phosphat-Dehydrogenase-Aktivität der Hefe und des Hämolysates. Niedrigere Konzentrationen beeinflußten die Glucose-6-phosphat-Dehydrogenase-Aktivität durch Entfernung hemmender Metallionen (Zinkionen), was zu einer Aktivierung führte. Im Hauthomogenat ließ sich nur eine derartige Aktivierung nachweisen. Das Zustandekommen der verschiedenen Wirkungen von $D$-Penicillamin auf die Glucose-6-phosphat-Dehydrogenase-Aktivität wird diskutiert.

\section{Introduction}

$D$-Penicillamine ( $\beta, \beta^{\prime}$-dimethylcysteine) is used in human therapy for an increasing number of diseases. The mechanisms whereby this interesting substance exerts its various therapeutic actions, are, however, not always fully understood. There is increasing interest in the changes in enzymatic activities evoked by $D$-penicillamine.

Biochemically, $D$-penicillamine acts as a chelating agent (e. g. chelation of copper ions in Wilson's disease), splits disulfide bonds (exchange reactions), and reacts with aldehyde groups (e. g. with aldehyde groups of pyridoxal-phosphate and tropocollagen). Important enzymes and enzyme systems may be influenced by $D$-penicillamine via all three of the above mechanisms. So far, an anti-collagenase effect of $D$-penicillamine has been reported (1) as well as an inhibitory action on alkaline phosphatase activity (2). The latter effect was attributable to a chelation of important ions. In further investigations, changes in glucose-6-phosphate dehydrogenase activity were encountered under the influence of $D$-penicillamine. As a contribution to the various biochemical actions of $D$-penicillamine, the results of these studies will be reported here.

\section{Methods and Materials}

Enzyme sources: Glucose-6-phosphate dehydrogenase (EC 1.1.1.49) activity has been investigated from three sources: from yeast (pure enzyme preparation, commercially available), from human hemolysate, and from human skin homogenates (Blendor: Ultraturrax). Details of preparations have been described elsewhere (3).

D-Penicillamine: D-Penicillamine (Biochemie, Vienna) dissolved in saline was added to the solutions with Glucose-6phosphate dehydrogenase activity. Incubation was performed at $3.7^{\circ} \mathrm{C}$ for $1 \mathrm{~h}$. In every instance, cnzymatic activity was compared to a control assay containing saline instead of $D$-penicillamine. Final concentrations of $D$-penicillamine ranged between $6.7 \mu \mathrm{mol} / 1$ (i. e. $1 \mu \mathrm{g} / \mathrm{l}$ ) und $335 \mathrm{mmol} / \mathrm{l}$ (i. e. $50 \mathrm{~g} / \mathrm{l}$ ).

Zinc ions: As the activity of glucose-6-phosphate dehydrogenase is known to be highly susceptible to the presence of zinc or other metal ions $(4,5)$, additional investigations werc performed with $D$-penicillamine and zinc ions. $\mathrm{Zn}\left(\mathrm{NO}_{3}\right)_{2} \times$ $4 \mathrm{H}_{2} \mathrm{O}(\mathrm{M}=261.5)$ was used. The effects of $D$-penicillamine 
(concentration range $6.7 \mu \mathrm{mol} / 1$ to $335 \mathrm{mmol} / \mathrm{l}$ ) on the activity of glucose-6-phosphate dehydrogenase of yeast (pure enzy'me) and of human hemolysate wcre determined in the presence of zine ions $(360 \mu \mathrm{mol} / \mathrm{l}$ which corresponds to $100 \mathrm{mg}$ zinc nitrate per litre). Furthermore, the inhibitory action of zinc ions (concentration range $3-360 \mu \mathrm{mol} / \mathrm{l}$, i. c. 1-100 mg zinc nitrute per litre) was recorded with and without $D$-penicillamine (concentration $67 \mu \mathrm{mol} / \mathrm{l}$ ), using the purc enzyme preparation only.

Determination of enzymatic activity: Glucose-6-phosphate dehydrogenase activity was assayed in the following way: $0.05 \mathrm{ml}$ of $31 \mathrm{mmol} / 1$ glucosi-6-phosphatc, $0.1 \mathrm{ml}$ of $10 \mathrm{mmol} / \mathrm{l} \mathrm{NADP}$, and $1.0 \mathrm{ml}$ of the test or control solution were added to $2.0 \mathrm{ml}$ of a $5 \mathrm{mmol} / \mathrm{l}$ tricthanolamine buffer pH 7.6 containing $5 \mathrm{mmol} / \mathrm{l}$ ethylencdiamine tetraacetatc. Immediately after mixing and temperature adaption $\left(25^{\circ} \mathrm{C}\right)$ cxtinction at $340 \mathrm{~nm}$ was read; readings were repeated after 1,2 , and $3 \mathrm{~min}$. Mean extinction difference per $\min$ was multiplied by 506 in order to calculate the $U(=\mu \mathrm{mol} X$ $\mathrm{min}^{-1}$ ) glucose-6-phosphate dehydrogenase activity per litre.

\section{Results}

\section{Pure enzyme from yeast}

Control activities in ten experiments with pure glucose6-phosphate dehydrogenase from yeast ranged between 45 and $50 \mathrm{U} / 1 . D$-Penicillamine caused an inhibition in concentrations above $1 \mathrm{~g} / \mathrm{l}(6.7 \mathrm{mmol} / \mathrm{l})$. In this study, a significant inhibition $(P<0.001)$ was found with two concentrations: 10 and $50 \mathrm{~g} / 1 D$. penicillamine (67 and $335 \mathrm{mmol} / \mathrm{l}$ ). The dose-response curve is shown in figure 1 .

The presence of zinc ions $(360 \mu \mathrm{mol} / \mathrm{l})$ inhibited glucose-6-phosphate dehydrogenase activity by $68 \%$ $(P<0.001)$.

The presence of increasing amounts of $D$-penicillamine depressed the above-described inhibitory action of zinc

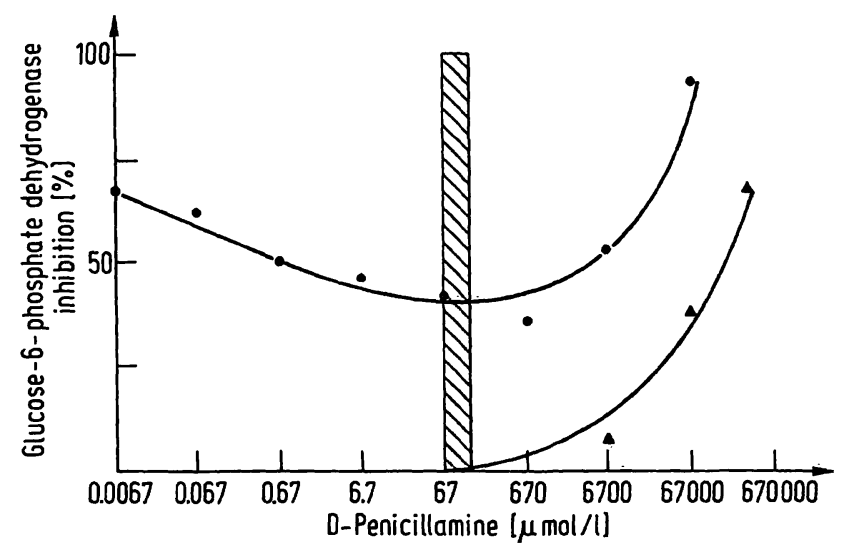

Fig. 1. Changes in glucose-6-phosphate dehydrogenase activity (pure enzyme from yeast) in the presence of $D$-penicillamine (concentrations between $1 \mu \mathrm{g} / 1$ and $50 \mathrm{~g} / \mathrm{l}$, i. e. $6.7 \mathrm{nmol} / \mathrm{l}$ and $335 \mathrm{mmol} / \mathrm{l})$ and zinc ions $\left(\mathrm{Zn}\left(\mathrm{NO}_{3}\right)_{2}\right.$ $\times 4 \mathrm{H}_{2} \mathrm{O}, 100 \mathrm{mg} / \mathrm{l}$, i. e. $\left.360 \mu \mathrm{mol} / \mathrm{l}\right)$ with $D$-penicillamine in the above mentioned concentrations.

$\longrightarrow$ Zinc ions and $D$-penicillamine $\triangle$ - $D$-penicillamine

The hatched column indicates therapeutic serum levels of $D$-penicillamine. ions. However, when the concentrations of $D$-penicillamine exceeded $670 \mu \mathrm{mol} / 1$, inhibition increased again. With $67 \mathrm{mmol} / \mathrm{l} D$-penicillamine and $360 \mu \mathrm{mol} / \mathrm{l}$ zinc ions, inhibition of glucose-6-phosphate dehydrogenase activity reached $95 \%$. This value proved to be.signiificantly higher $(\mathrm{P}<0.001)$ than the inhibition produced by zinc ions alone. For details, cf. figure 1 . The doseresponse curve depicting the inhibition of glucose-6phosphate dehydrogenase activity by zinc ions in concentrations between $3.0 \mu \mathrm{mol} / \mathrm{l}$ and $1.8 \mathrm{mmol} / \mathrm{l}(1$ and $500 \mathrm{mg} / \mathrm{l}$ zinc nitrate) was the same as publis'icd in a previous paper (5). The presence of $67 \mu \mathrm{mol} / 1 D$ penicillamine weakened this inhibitory action over the whole concentration range; the encountered changes measured about $5 \%$ with the lower zinc concentrations and $10 \%$ with the higher zinc concentrations. A statistical significance could not be obtained $(P>0.05)$.

\section{Hemolysate}

In five different hemolysates, control activities measured 55 to $65 \mathrm{U} / 1$. The inhibitory action of $D$. penicillamine was found to be lower and amounted to a significant value in the highest concentration (335 mmol $/ 1, \fallingdotseq 50 \mathrm{~g} / \mathrm{l} ; 27 \%$ inhibition; $\mathrm{P}<0.001$ ), only. Details are shown in figure 2.

Zinc ions in a concentration of $360 \mu \mathrm{mol} / \mathrm{l}$ provoked a complete inhibition of glucose-6-phosphate dehydrogenase activity of human hemolysates.

The presence of $D$-penicillamine in increasing concentrations produced an increasing deterioration of the above-described inhibitory action of zinc ions. With $D$-penicillamine in concentrations between 0.67 and $67 \mathrm{mmol} / \mathrm{l}$, the inhibitory action of zinc ions $(360 \mu \mathrm{mol} / \mathrm{l})$ was no longer significant (only $10 \%$ inhibition; $P>0.05$ ). In the assays with $335 \mathrm{mmol} / \mathrm{l}$ $D$-penicillamine and $360 \mu \mathrm{mol} / 1$ zinc ions, glucose-6phosphate dehydrogenase activity of the hemolysates was significantly inhibited ( $29 \%$ inhibition; $P<0.001$ ). This value corresponded to the inhibition obtained with $335 \mathrm{mmol} / 1 D$-penicillamine without zinc ions (cf. fig. 2).

\section{Human skin homogenates}

In five fresh human skin homogenates, control values of glucose-6-phosphate dehydrogenase activity ranged between 17 and $35 \mathrm{U} / 1$. In old homogenates (stored overnight at $-30^{\circ} \mathrm{C}$ ), glucose-6-phosphate dehydrogenase activities measured only half of the abovementioned activities.

In concentrations between $67 \mu \mathrm{mol} / 1$ and $67 \mathrm{mmol} / \mathrm{l}$, $D$-penicillamine provoked an activation of glucose-6: phosphate dehydrogenase activity in both fresh and old human skin homogenates. Significant activation was found with concentrations of $670 \mu \mathrm{mol} / 1$ and above $(P<0.001)$. As shown in figure 3 , this effect of activation was more pronounced in ,old" homo- 


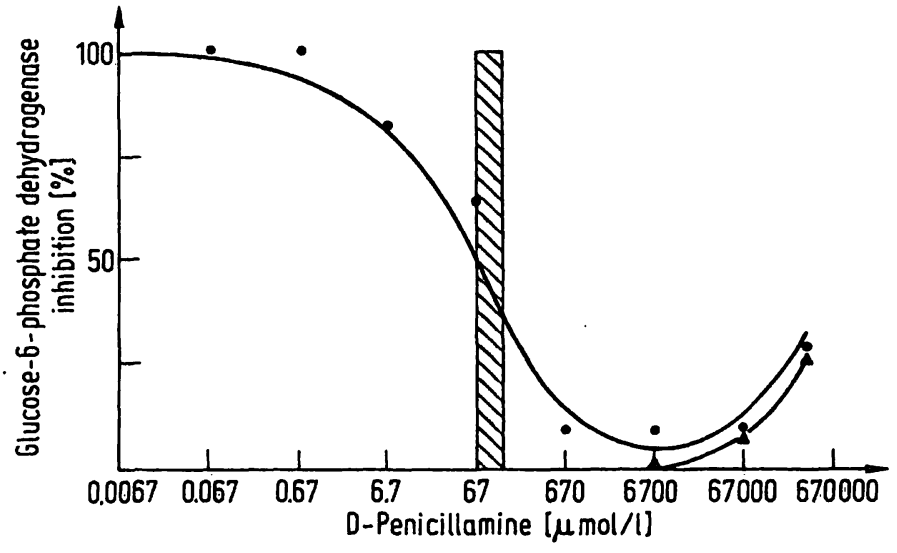

Fig. 2. Changes in glucose-6-phosphate dehydrogenase activity of human hemolysate in the presence of $D$-penicillamine (concentrations between $1 \mu \mathrm{g} / 1$ and $50 \mathrm{~g} / \mathrm{l}$, i. e. $6.7 \mathrm{nmol} / \mathrm{l}$ and $335 \mathrm{mmol} / \mathrm{l})$ and zinc ions $\left(\left(\mathrm{Zn}\left(\mathrm{NO}_{3}\right)_{2} \times 4 \mathrm{H}_{2} \mathrm{O}\right.\right.$, $100 \mathrm{mg} / \mathrm{l}$, i. e. $360 \mu \mathrm{mol} / \mathrm{l})$ with $D$-penicillamine in the above-mentioned concentrations.

$\longrightarrow$ Zinc ions and $D$-penicillamine $\Delta-\Delta$-penicillamine

The hatched column indicates therapeutic serum levels on $D$-penicillamine in humans.

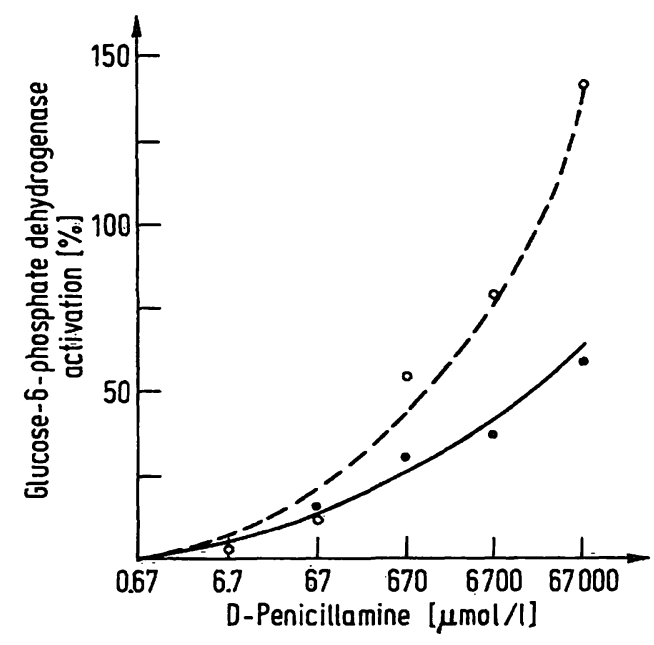

Fig. 3. Changes in glucose-6-phosphate dehydrogenase activity of human skin homogenates in the presence of $D$-penicillamine (concentrations between $0,1 \mathrm{mg}$ and $10 \mathrm{~g} / \mathrm{l}$, i. e. $6.7 \mathrm{nmol} / 1$ and $67 \mathrm{mmol} / \mathrm{l})$. Two types of homogenates are depicted: low control activity $5.9 \mathrm{U} / 1(0---0)$ and high control activity $17.2 \mathrm{U} / 1(\bullet-\bullet)$.

genates with low control activity. Figure 3 presents the results of a typical experiment with one skin preparation (fresh and old homogenate).

\section{Discussion}

In pure enzyme preparations as well as in the human hemolysate, a direct inhibitory action of $D$-penicillamine on glucose-6-phosphate dehydrogenase activity was seen. However, high concentrations of $D$-penicillamine were needed to provoke such an effect (cf. fig. 1 and 2). The occurence of such inhibitory action can be ascribed to the well-known reaction of $D$-penicillamine with sulfhydryl groups. Via this mechanism, an influence on active sites of the enzyme protein may be exerted, leading to an inhibition of enzymatic activity.

Zinc ions could be shown to inhibit both pure glucose6-phosphate dehydrogenase from yeast and glucose-6phosphate dehydrogenase from hemolysate. However, the glucose-6-phosphate dehydrogenase of hemolysate was more sensitive. The presence of $D$-penicillamine has been found to block partially the inhibitory action of zinc ions on glucose-6-phosphate dehydrogenase activity. With higher concentrations of $D$-penicillamine, however, this effect is lost, most probably due to the fact that the direct inhibitory action of $D$-penicillamine is beginning to have an effect.

In the skin homogenates, no inhibitory action of $D$. penicillamine on glucose-6-phosphate dehydrogenase activity could be found. On the contrary, an activation of this enzymatic activity occurred with increasing concentrations of $D$-penicillamine. As glucose-6-phosphate dehydrogenase is an enzyme with high susceptibility to zinc and various other metal ions (4) it seems logical to assume that $D$-penicillamine activates glucose-6-phosphate dehydrogenase by removing metal ions (chelating effect). More difficulties arise when one tries to explain why $D$-penicillamine provokes a stronger activation of lower enzymatic activity (compare the two curves in fig. 3). May be the enzyme in the "old" preparation is more susceptible to the influence of metal ions; another explanation could be given by the assumption of a direct influence of $D$-penicillamine on the enzyme protein in an altered state (artificial S-S bridges after prolonged storage).

For practical therapeutical purposes, a direct influence of $D$-penicillamine does not seem to be of importance; the concentrations needed for such effect are not reached in human therapy. On the other hand, pharmacokinetic studies $(6,7)$ show that serum levels of 10 to $20 \mathrm{mg} / \mathrm{l}$ are attained with some commonly used regimens of $D$-penicillamine therapy. As shown in figures 1 and 2 , such concentrations may influence enzymatic activities by chelating metal ions. Such metal ions either can act as inhibitors (as it is the case with glucose-6phosphate dehydrogenase), or as activators (cf l.c. (2)).

Relatively high concentrations of $D$-penicillamine are reached in the skin $(6,7)$. Levels of 40 to $60 \mu \mathrm{g} / \mathrm{g}$ may be reached. Again, no direct effect of $D$-penicillamine on glucose-6-phosphate dehydrogenase activity can be assumed but an indirect effect (chelation of metal ions) is most likely to occur. The absence of direct (inhibitory) $D$-penicillamine effects in skin homogenates may be ascribed to binding to proteins or other substances in the homogenates. 


\section{References}

1. François, J., Cambic, E. \& Feher, J. (1973), Ophthalmologica $166,222-225$.

2. Raab, W. \& Mörth, Cl. (1974), this j. 12, 309-310.

3. Raab, W. \& Siber, H. (1974), Arch. Dermatol. Forsch. 249, 179-189.

4. Mangiarotti, G., Garre, C., Acquarone, M. A. \& Silengo, L. (1966), G. Biochim. 15, 67-76, Cit. Chem. Abstr. 66, 35021x, (1967).

5. Raab, W. \& Gmeiner, B. (1974), Arch. Dermatol. Forsch. 251, 87-94.

6. Planas-Bohne, F. (1972), Arzneim.-Forsch. 22, 1426-1433.

7. Ruiż-Torres, A. 1974), Arzneim.-Forsch. 24, 914-917, 1043-1046, 1258-1261.

Univ. Doz. Dr. Wolfgang Raab

Waehringerstriaße 10

A-1090 Vienna, Austria 